\title{
Biogeography of Matsucoccus josephi Bodenheimer et Harpaz in Crete and mainland Greece *
}

\author{
Z Mendel, G Schiller \\ Departments of Entomology and Field Crops and Natural Resources, \\ Agricultural Research Organization, The Volcani Center, Bet Dagan 50250, Israel
}

(Received 2 October 1992; accepted 16 March 1993)

Summary - Surveys have been conducted in natural and planted stands of brutia pine (Pinus brutia Ten subsp brutia) and Aleppo pine ( $P$ halepensis Mill) to ascertain the possible occurrence of Israeli pine bast scale Matsucoccus josephi Bodenheimer et Harpaz (Homoptera: Matsucoccidae) and its typical associates in mainland Greece and on the islands of Thasos and Crete. Our findings show that in mainland Greece between 21-24 longitude E, $M$ josephi is absent from both brutia pine and Aleppo pine. The absence of $M$ josephi from brutia pine in Chalkidiki and the island of Thasos raises the possibility that the tree has been introduced by man without the scale insect; the introduction by seed from Asia Minor could have been made for the production of honeydew by Marchalina hellenica Gennadius (Homoptera: Margarodidae) whose excretions are the main source of honey in those areas. The occurrence of $M$ josephi in Turkey and Crete and its absence from Aleppo pine in mainland Greece tend to confirm that brutia pine is the principal host of the scale. Brutia pine and $M$ josephi could have migrated together via the remnants of the land bridge connecting southeast Anatolia to Crete some $4-5$ million years ago.

Matsucoccus josephi / Pinus brutia / Pinus halepensis / Greece / Crete

Résumé - La biogéographie de Matsucoccus josephi Bodenheimer et Harpaz en Crète et Grèce continentale. Des visites ont été conduites en Grèce continentale et dans les îles de Thasos et Crète, dans des peuplements autochtones et artificiels de pin brutia (Pinus brutia Ten subsp brutia) et pin d'Alep ( $\mathrm{P}$ halepensis Mill) pour vérifier la présence éventuelle du $\mathrm{M}$ josephi Bodenheimer et Harpaz (Homoptera: Matsucoccidae) et de ses espèces associees typiques. II en résulte qu'en Grèce continentale, entre les méridiens de $21^{\circ}-24^{\circ} \mathrm{E}, \mathrm{M}$ josephi $n^{\prime}$ est présent ni sur le pin brutia ni sur le pin d'Alep. L'absence de Matsucoccus sur le pin brutia en Chalcidique et à Thasos suggère la possibilité de l'introduction du pin par l'homme. Cette introduction, au moyen de graines provenant d'Asie Mineure, pourrait avoir eu pour but la production de miellat par Marchalina hellenica Gennadius (Homoptera: Margarodidae), la principale source de miel dans ces régions. La présence de $\mathrm{M}$ josephi en Turquie et Crète sur le pin brutia et son absence en Grèce continentale sur le pin d'Alep

* Contribution from the Agricultural Research Organization, the Volcani Center, Bet Dagan, Israel, No 3644-E 1992 series. 
tendent à confirmer la conclusion formulée antérieurement selon laquelle le pin brutia est le principal hôte du Matsucoccus. La migration simultanée du pin brutia et de $\mathrm{M}$ josephi a pu avoir lieu il y a 4-5 millions d'années, lorsque la Crète était reliée au SE de l'Anatolie.

Matsucoccus josephi / Pinus brutia / Pinus halepensis / Grèce / Crête

\section{INTRODUCTION}

The Israeli pine bast scale Matsucoccus josephi Bodenheimer et Harpaz (Homoptera:Matsucoccidae) is the most noxious insect in native Aleppo pine, Pinus halepensis Mill and introduced Pinus brutia Ten ssp eldarica (Medw) Nahal in Israel (Mendel et al, 1988). The scale settles on all above-ground parts of the tree. During feeding it secretes a poisonous saliva that disrupts water transport and results in the death of new growth or the entire tree (Mendel and Liphschitz, 1988). The scale was first discovered in Israel in 1933 on Mt Carmel ; a few years later, mass mortality of Aleppo pine seedlings in newlyreforested areas near Mt Carmel was noted (Bodenheimer and Neumark, 1955). Since the 1980s, the scale has infested all major pine plantations in Isreal, causing severe damage to Aleppo pine and Eldar pine, $\approx 30 \%$ of the stands of the former being severely injured (Mendel et al, 1988). The pest was believed to be endemic on natural Aleppo pine. Scale population outbreaks resulting in widespread mortality have been found to be related to large-scale planting of Aleppo pine over a relatively short time period, unsuitable seed collection practices and use of susceptible seed sources (Mendel, 1984). M josephi also occurs naturally in Turkey and Cyprus on brutia pine, Pinus brutia Ten spp brutia, its principal host (Mendel, 1992). In both these countries as well as in Israel the insect is usually present at low densities on brutia pine and damage is practically nil.
Aleppo pine and brutia pine are usually taken as allopatric and their natural range consists of spatially isolated populations (Panetsos, 1981 ; Nahal, 1983), with isozyme analysis providing evidence of intraspecific variation (Schiller et al, 1986 ; Conkle et al, 1988). Isolated occurrences of one species within the range of the other have been attributed to human intervention (Panetsos, 1981 ; Schiller et al, 1986). Aleppo pine is planted in Cyprus, whereas in Turkey supposedly natural stands of Aleppo pine forming small enclaves within brutia pine forests (Kayacik, 1973) are most probably the result of introduction by man (Schiller et al, 1986 ; Schiller and Mendel, 1992). Infestation of Aleppo pine by the scale in Cyprus and Turkey are the result of its spread from nearby brutia pine stands. Brutia pine is highly resistant to infectation by $M$ josephi (Mendel and Liphschitz, 1988) ; among provenances of Aleppo pine, the Greek seed sources are the least susceptible (Mendel, 1984). From the presence of $M$ josephi in Israel, Turkey and Cyprus it could have been expected that the scale would also occur west of longitude $25^{\circ} \mathrm{E}$, the main area of distribution of $P$ halepensis. Yet there are no reports of its occurrence in Spain, France and Italy by entomologists thoroughly familiar with the genus and engaged in research on Matsucoccus feytaudi Ducasse, a major pest of Pinus pinaster Ait, nor has the scale been observed in Morocco (F Assael, personal communication).

The presence of $M$ josephi in Israel is possibly the outcome of southward migration of brutia pine reaching the distribution 
area of Aleppo pine in the environs of Beirut (Mouterde, 1947), and/or the import of brutia pine timber or planting stock from Cyprus (eg Mendel, 1990). Thus, it was reasonable to expect the scale to also occur in eastern Greece where Aleppo pine comes into contact with brutia pine and interspecific hybrids occur (Papaioannou, 1936). The distance between Aleppo pine on Mt Athos, Chalkidiki, and brutia pine on the island of Thasos is $\approx 50 \mathrm{~km}$ as the crow flies, and would provide no insurmountable obstacle to the dispersal of the scale.

As part of the study on the biogeography of $M$ josephi, surveys were conducted in 1992 in natural and planted stands of brutia pine and Aleppo pine in Greece to ascertain the possible occurrence of the scale in mainland Greece and on the islands of Thasos and Crete.

\section{MATERIALS AND METHODS}

\section{Study procedure}

Sixteen stands of brutia pine and Aleppo pine were investigated in March-April 1992. Stands of brutia pine were examined in the following areas (the letters refer to the location of the sites in figure 1): Chalkidiki, natural (or supposedly natural) brutia pine near Annea and Mademlako (a) ; the west part of Crete near Prasas (b) and Anapolis (c) ; Thasos, 3 sites (d) ; and planted trees in Piraeus (e). Aleppo pine was examined in the following localities: Chalkidiki, near Annea and Stratonia (f) ; the Peloponnese, near Olympia $(g)$, Kalogria $(h)$; and a plantation near Corinth (i).

At each site 10-50 trees of different ages, if possible 8-15-yr-old, were examined. In $\mathrm{Ma}$ demlako only 5 mature trees including the upper parts of the stems and $\approx 30$ seedlings from natural regeneration were inspected. Light infestation with live scales can be expected to occur on stem parts during the initial stages of bark peeting ; however, dead larvae and exuviae of $M$ jo- sephi, if present, can easily be found under older flakes. Dead larvae and exuviae remain on the stem for many years ; therefore a simple visit may permit definite conclusions to be made on the presence or absence of the insect. The bark flakes of the sampled parts were removed, and live and dead adult females were collected with a fine brush. Natural enemies and associated insects were removed from the bark surface with an aspirator. Identification of $M$ josephi was made by comparison of microscopic slides of adult females from Crete with those of Israeli females.

\section{RESULTS AND DISCUSSION}

Our findings show that in mainland Greece between $21-24^{\circ}$ longitude $\mathrm{E}, M$ josephi is absent from both brutia pine and Aleppo pine ; (the occurrence on brutia pine of $M$ josephi in eastern Greece, which was not visited, needs further investigation). The insect was recorded only from the island of

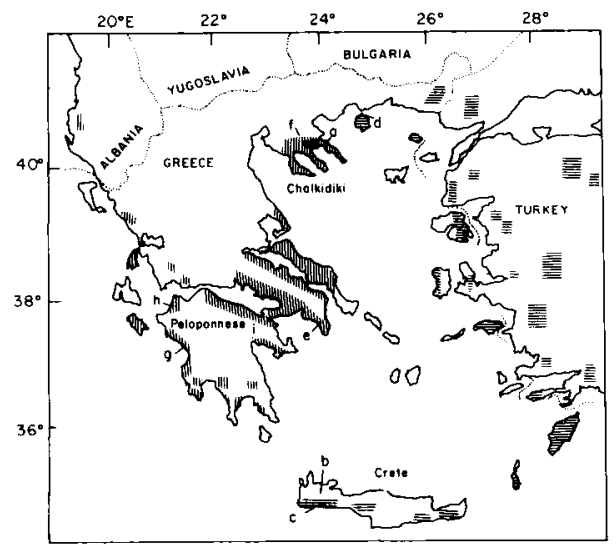

Fig 1. Locations sampled for occurrence of Matsucoccus josephi in Greece. a: Annean and $\mathrm{Ma}$ demlako; $b$ : Prasas; $c$ : Anapolis; $d$ : Thasos; e: Piraeus; f: Stratonia; g: Olympia; h: Kalogria; i: Corinth. Approximate natural distribution of Pinus halepensis (vertical bars) and $P$ brutia ssp brutia (horizontal bars) modified after Critchfield and Little (1966) and Panetsos (1975). In Greece, $M$ josephi was found only in Crete. 
Crete at very low densities, ie a single dead larva or empty exuvia per 1000 $2000 \mathrm{~cm}^{2}$ bark area suitable for infestation. Live larvae or adults were found on only a few trees. Among the natural enemies of Matsucoccus, Elatophilus $\mathrm{sp}$ (Hemiptera: Anthocoridae) (6 larvae and 1 adult) was collected only at Anapolis (Crete) from a single tree. Still unidentified pseudoscorpions (Pseudoscorpionidae) were found in all brutia pine stands (except for the planted trees at Piraeus) but not from any of the Aleppo pine investigated. At Prasas (Crete) $M$ josephi was associated with Marchalina hellenica Gennadius (Homoptera: Margarodidae). The density of $M$ josephi in Crete is similar to that on brutia pine in southern Turkey, but is markedly lower than that in Cyprus (Mendel, 1992). The presence of the specialized predator, Elatophilus $\mathrm{sp}$, in Crete provides additional evidence of the native occurrence of the scale on the island (eg Mendel et al, 1991).

The $\approx 30$ species of Matsucoccidae are obligatory parasites of pine ; each species develops on 1 or a few host species of a given subsection or section of the genus Pinus (Rieux, 1975 ; Ray, 1982 ; Liphschitz and Mendel, 1989). Bast scales are rare in their native habitats or occur at very low densities and are not considered serious pests. However, severe outbreaks resulting in most cases in the destruction of large forest areas are the outcome of the introduction of Matsucoccus spp into environments stocked with susceptible genotypes of the host tree or with related susceptible pines (Bean and Godwin, 1955 ; $\mathrm{Li}$ et al, 1980 ; Schvester and Ughetto, 1986 ; Binazzi and Covassi, 1987). M josephi develops only on taxa of the subsection Halepenses, viz $P$ halepensis and subspecies of $P$ brutia (Liphschitz and Mendel, 1989). $P$ brutia subsp brutia from its entire natural range, including seed sources from Crete and Greece, is highly resistant to infestation by the scale, whereas Aleppo pine is susceptible (Mendel, 1984). Resistance to $M$ josephi is most probably acquired through long coevolution between brutia pine and the scale. Hence, Eldar pine, Pinus brutia subsp eldarica, is highly susceptible to the scale because of its absence in the natural range of the tree (Mendel, in preparation). The heavy losses of Aleppo pine in Israel due to outbreaks of $M$ josephi may be due to the fact that the insect was introduced from abroad (Mendel et al, submitted for publication).

Brutia pine is taken to be native to Crete and is widely distributed from high elevations to almost sea level (Zohary and Orshan, 1965) ; thus, its range bears some resemblance to that in Turkey. Panetsos (1981), discussing the distinctive features of provenances of brutia pine, suggests that the trees from Crete differ clearly from the rest of the subspecies. Hence, brutia pine from Crete was probably isolated from its main range in Anatolia earlier than the population of Thrace (northeastern Greece). We suggest that brutia pine and $M$ josephi could have migrated together via the land bridge from southeast Anatolia to Crete some 4-5 million years ago (the island was disconnected from the mainland only between the late Miocene and the Pliocene) (Steininger and Rogl, 1984). The maximum rise in eustatic level by $150 \mathrm{~m}$ of the Ionian Sea during the Quaternary (Fabricius, 1984) did not eliminate brutia pine and its fauna from the more elevated areas in Crete. However, the possibility cannot be dismissed that brutia pine became extinct due to human activity in the past 5000 $y r$ and that it was later reintroduced to the island. If indeed this is the case, the introduction must have been made by planting saplings, since Matsucoccus spp cannot be transferred by seed.

If the occurrence of brutia pine in Chalkidiki and Thasos is the result of the west- 
ward migration from Asia Minor, one would expect scale to occur there as well. The absence of $M$ josephi on brutia pine in Greece raises the question whether the occurrence of the tree there is the outcome of artificial introduction. Both Aleppo pine and brutia pine are used for resin tapping and bee grazing in Western Turkey and Greece. The former produces twice as much resin as the latter (Panetsos, 1975 ; Papagiannopoulos, 1983). Papaioannou (1954) recommended the removal of brutia pine in areas of contact between the species in order to preserve the high resin yield of Aleppo pine, as he considered that hybridization could lower yields. On the other hand, brutia pine due to its longer period of intensive growth than that of Aleppo pine may be a better host than the latter for Marchalina hellenica whose honeydew is the main source of honey in Chalkidiki, Thasos, Crete and Western Turkey (Crane and Walker, 1985). Artificial infestation of pines with $M$ hellenica is a longestablished tradition (ND Avtzis, personal communication). Thus, introduction of brutia pine from Asia Minor to Chalkidiki and Thasos could have been aimed at high honeydew production by $M$ hellenica. The pine must have been raised from imported seed, since transfer of wildlings or nursery stock which are suitable hosts of $M$ josephi would have resulted in the introduction of the scale into areas where it was previously absent. For example, brutia pine is known to have been planted on Princes' Islands in the Sea of Marmara (Schimitschek, 1944 ; Mendel, 1992), and the presence of both $M$ hellenica and $M$ josephi doubtlessly accounts for the use of saplings.

In conclusion, the presence of $M$ josephi on $P$ brutia subsp brutia is believed to be evidence of the autochthonous character of the pine in Crete. The absence of scale on brutia pine in northeastern mainland Greece and the offshore island of Thasos indicates an artificial introduction of the tree.

\section{ACKNOWLEDGMENTS}

We express our gratitude to all those who assisted us during this study: to our Israeli colleagues, F Assael and S Tam ; to our Greek colleagues from Thessaloniki, ND Avtzis, CP Panetsos, and ME Tzanakakis ; to SE Michelakis from Hania, Crete, and $H$ Douma-Petridou from Patras. We would also like to thank $Y$ Ben-Dov, Volcani Center, for his help in identification of the scale. The study was partly supported by the Forests Department of the Jewish National Fund as Project No 131-0637.

\section{REFERENCES}

Bean JL, Godwin PA (1955) Description and bionomics of a new pine scale, Matsucoccus resinosae. For Sci 1, 164-176

Binazzi A, Covassi M (1987) II Matsucoccus feytaudi Ducasse nelle pinete Ligurii di ponente. In: Academia Nazionale Italiana di Entomologia. Convegno da Legno Awersita del Bosco e Delle Specie Arboree da Legno. Florence, 15-16 October 1987, 197-222

Bodenheimer FS, Neumark S (1955) The Israeli Pine (Matsucoccus). Kiryat Sepher, Jerusalem

Conkle MT, Schiller G, Grunwald C (1988) Electrophoretic analysis of diversity and phylogeny of Pinus brutia and closely related taxa. System Bot 13, 411-424

Crane E, Walker $P$ (1985) Important honeydew sources and their honeys. Bee World 66, 105-112

Critchfield WB, Little EL (1966) Geographic Distribution of the Pines of the World. USDA For Sen Misc Publ 991

Fabricius FH (1984) Neogene to Quaternary geodynamics of the area of the lonian Sea and surrounding land masses. In: The Geological Evolution of the Eastern Mediterranean (Dixon JE, Robertson AHF, eds) Blackwell, London, 819-824

Kasapligil B (1978) Past and present pines of Turkey. Phytologia 40, 99-199

Kayacik H (1973) Pines in Turkey and an investigation about their geographical distribution, 
III Aleppo pine ( $P$ halepensis Mill). Orman Fakultesi Dergisi Ser A 23, 147-160 (in Turkish, with English summary)

Li G, Zhuang L, Han R, Liu X, Xia R (1980) A study of the pine stem coccid Matsucoccus matsumurae Kuwana. Rep Inst Lianoing Prov 9, 1-27 (in Chinese, with English summary)

Liphschitz N, Mendel Z (1989) Interactions between hosts and non-hosts of Pinus spp and Matsucoccus josephi. anatomical responses of the stem to infestation. New Phytol 113, 135-142

Mendel $Z$ (1984) Provenance as a factor in susceptibility of Pinus halepensis to Matsucoccus josephi (Homoptera:Margarodidae). For Ecol Manage 9, 259-266

Mendel Z (1990) Origin of the pine processionary caterpillar Thaumetopoea wilkinsoni Tams (Lep Thaumetopoeidae) in Israel. J Appl Entomol 109, 311-314

Mendel $Z$ (1992) The occurrence of Matsucoccus josephi in Cyprus and Turkey and its relation to decline of Aleppo pine. Entomol Gen 17, 299-306

Mendel Z, Carmi E, Podoler H (1991) Relations between the genera Matsucoccus (Homoptera: Margarodidae) and Elatophilus (Hemiptera: Anthocoridae) and their significance. Ann Entomol Soc Am 84, 502-507

Mendel Z, Liphschitz N (1988) Unseasonal latewood and encrusted pits are the cause of dyring in Pinus halepensis and Pinus eldarica infested with Matsucoccus josephi. Jour Exp Bot 39, 951-959

Mendel Z, Saphir N, Madar Z, Golan Y, Speter E, Zehavi A (1988) The effect of habitat and age of Aleppo pine plantations on the damage caused by Matsucoccus josephi. Hassadeh 68, 2203-2207 (in Hebrew)

Mouterde $P$ (1947) La Végétation Arborescente des Pays du Levant. Publ École Française d'Ingénieurs, Beirut, No 13

Nahal I (1983) Le pin brutia (Pinus brutia subsp brutia). For Méd 2, 165-172

Panetsos CP (1975) Natural hybridization between Pinus halepensis and $P$ brutia in Greece. Silvae Genet 24, 163-168

Panetsos CP (1981) Monograph of Pinus halepensis (Mill) and $P$ brutia (Ten). Ann For Zagreb $9,39-77$
Papagiannopoulos AD (1983) Studies on the resin tapping of Pinus halepensis and $P$ brutia: productivity, resin flow factors and mechanism, and anatomical effect of tapping (English abstract of a thesis in Greek, Department of Forests and Natural Environment, Aristoteleian University, Thessaloniki, Greece); For Abstr (1986) 47-01456

Papaioannou J (1936) Uber Artbastarde zwischen Pinus brutia Ten und Pinus halepensis Mill in Chalkidiki (Griechenland). Forstwiss Zentralb/ 58, 194-205

Papaioannou J (1954) Hybridization of Mediterranean pines and its influence on resin production and especially in Greece. Dasos 2528, 104-106 (in Greek)

Ray CR (1982) Revision of the genus Matsucoccus (Homoptera: Coccoidea:Margarodidae) in North America. PhD Thesis, Auburn Univ, Auburn/Alabama, AL

Rieux R (1975) La spécificité alimentaire dans le genre Matsucoccus (Homoptera: Margarodidae) avec référence spéciale aux planteshôtes de $M$ pini Green. Classement des Matsucoccus d'après leurs hôtes. Ann Sci For 32, 157-168

Schiller G, Conkle MT, Grunwald C (1986) Local differentiation among Mediterranean populations of Aleppo pine in their isoenzymes. Silvae Genet 35, 11-19

Schiller G, Mendel Z (1992) On the origin of $P$ inus halepensis Mill in Turkey: synthesis of genetic and entomological studies. In: (Docum) Int Sympt Popul Genet Gene Conservation For Trees. Bordeaux, France, August 1992

Schimitschek E (1944) Forstinsekten der Turkei und ihre Umwelt. Volk und Reich, Prague

Schvester D, Ughetto F (1986) Différences de sensibilité a Matsucoccus feytaudi Ducasse 1942 (Coccoidea:Margarodidae) selon des provenances de pin maritime (Pinus pinaster Ait). Ann Sci For 43, 459-474

Steininger FF, Rogl F (1984) Paleogeography and palinspastic reconstruction of the Neogene of the Mediterranean and Paratethys. In: The Geological Evolution of the Eastern Mediterranean (Dixon JE, Robertson AHF, eds) Blackwell, London, 659-668

Zohary M, Orshan G (1965) An outline of the geobotany of Crete. Suppl Israel J Bot 14, 1 49 